\title{
Factors Associated with Coronavirus Disease 2019 Prevention Practices in Three Zones of Southwest Ethiopia: Community-Based Cross-Sectional Study
}

This article was published in the following Dove Press journal:

International Journal of General Medicine

\author{
Wondimagegn Wondimu (D) \\ Amare Ejigu (1D ${ }^{2}$ \\ Mengistu Ayenew $\mathbb{B D}^{1}$ \\ Angesom Weldu Kidnau' \\ Wondwossen Niguse (D) $^{3}$ \\ Mesfin Geremaw ${ }^{4}$ \\ Gizachew Ayele Manaye $\mathbb{D I}^{5}$ \\ Ashenafi Assefa Berchedi ${ }^{3}$ \\ 'Department of Epidemiology and \\ Biostatistics, School of Public Health, \\ College of Medicine and Health Science, \\ Mizan-Tepi University, Mizan Aman, \\ Ethiopia; ${ }^{2}$ Department of Midwifery, \\ College of Medicine and Health Science, \\ Mizan-Tepi University, Mizan Aman, \\ Ethiopia; ${ }^{3}$ Department of Nursing, \\ College of Medicine and Health Science, \\ Mizan-Tepi University, Mizan Aman, \\ Ethiopia; ${ }^{4}$ Department of Public Health, \\ College of Medicine and Health Science, \\ Mizan-Tepi University, Mizan Aman, \\ Ethiopia; ${ }^{5}$ Department of Medical \\ Laboratory, College of Medicine and \\ Health Science, Mizan-Tepi University, \\ Mizan Aman, Ethiopia
}

Background: The cases of coronavirus disease 2019 (COVID-19) and related deaths are increasing exponentially in Ethiopia. Prevention is currently available effective management, and its implementation has not been assessed adequately. This study aimed to identify the factors associated with COVID-19 prevention practices in three zones of southwest Ethiopia. Methods: A community-based cross-sectional study was conducted in the Bench Sheko, Kafa, and West Omo zones. A multistage sampling technique was employed to select 845 study participants. The data collection tool was adapted from the WHO resources and related literature. Independent factors were identified using binary logistic regression and a p-value less than 0.05 was used to declare the level of statistical significance.

Results: In this study, 803 participants participated. About two-thirds $(64.7 \%)$ of the respondents had a history of going to crowded places, while only $30.3 \%$ of the participants had a history of wearing a mask when leaving home. Two-thirds of the respondents had a history of maintaining their distance at 2 meters $(64.4 \%)$ and washing their hands with soap and water or using alcohol-based hand sanitizers $(64.8 \%)$. Generally, less than two-thirds (59.4\%) of study participants had a good prevention practices of COVID-19. Urban residence (AOR [adjusted odds ratio] $=2.34 ; 95 \% \mathrm{CI}=1.39,3.94)$, highest family size $(\mathrm{AOR}=2.95 ; 95 \% \mathrm{CI}=1.56,5.57)$, good knowledge $(\mathrm{AOR}=1.74 ; 95 \% \mathrm{CI}=1.10,2.77)$, positive attitude $(\mathrm{AOR}=1.86 ; 95 \% \mathrm{CI}=1.27,2.73)$, intention to seek care $(\mathrm{AOR}=1.73 ; 95 \%$ $\mathrm{CI}=1.13,2.63)$, and perceived mortality $(\mathrm{AOR}=2.20 ; 95 \% \mathrm{CI}=1.50,3.08)$ were positively associated with good prevention practices.

Conclusion: The proportion of individuals who had good COVID-19 prevention practices was inadequate. For such highly infectious diseases, prevention should be the priority intervention, and improving its implementation needs further effort. Community-based interventions such as risk communication and mass education should center on scaling up community knowledge and practice by prioritizing vulnerable groups such as rural residents. Keywords: COVID-19, coronavirus, southwest Ethiopia, prevention, community based practice, Kafa, Bench Sheko, West Omo

\section{Introduction}

Department of Epidemiology and Biostatistics, School of Public Health, College of Medicine and Health Sciences, Mizan-Tepi University, Mizan Aman, Ethiopia

Email wonde1983.ww@gmail.com
Coronavirus disease 2019 (COVID-19) is an emerging contagious respiratory infection that brings a large puzzle to global health and has become an international concern. ${ }^{1}$ It is challenging the health system of the world, and surprisingly, 
countries with strong health systems are not spared. ${ }^{2,3}$ In addition to its health impact, it is leading to economic, political, and social crises. ${ }^{4-6}$

Since its emergence, the disease has reached 216 countries/territories, infected more than 69 million people, and took $1,488,120$ lives globally as of December $03,2020 .^{7}$ In Ethiopia, the disease was first reported on March 13, $2020 .^{8}$ Following this, the government of Ethiopia took different measures, such as isolating international passengers, arranging quarantine centers in different sites to follow the suspects, closure of universities and schools, mass disinfection, complete transport lockdown, and the release of prisoners. ${ }^{9}$ As per the Ethiopian Public Health Institute (EPHI) report of December 02, 2020, the total number of cases and deaths were 110, 984 and 1745 respectively. ${ }^{10}$

As occurred in high-income countries during the emergence of the outbreak, currently, in Ethiopia the number of cases and related deaths are increasing exponentially compared to those reported before a few months, which is suggestive of community transmission. ${ }^{9,11}$

The pandemic of COVID-19 has put health systems under immense pressure and stretch beyond their capacity, particularly those found in low-income countries are vulnerable. $^{2,12}$ As a result, different community-based interventions such as awareness creation, contact tracing, community level provision of other essential health services and home level management of non-severe COVID-19 cases are designed to reduce the burden of health facilities. These responsibilities are mainly carried out by the community health workforces and key community members because they are trusted members of the community with important links to the facilities, leaders, and organizations that are key contributors to an effective response. ${ }^{13,14}$

Currently, the disease has no cure, and prevention is the only available effective weapon to control it. The recommended methods to prevent the pandemic of COVID-19 include regular and thorough cleaning of hands with an alcohol-based hand rub or washing them with soap and clean water, maintaining a physical distance of at least 2 meters, avoiding going to crowded places, and wearing a facemask. ${ }^{15}$

Ethiopia is among the countries with a weak health system where the health professional to population ratio is only 0.96 per 1000 populations. This is much lower than the World Health Organization's recommended standards (4.45 per 1000 populations) to meet the sustainable development goal health targets. ${ }^{16,17}$ This implies that if our globe becomes lucky and obtains effective treatment for COVID-19, Ethiopia will still be far away from providing treatment for those who will be in need. As a result, maintaining the recommended prevention methods in the country is the first available option to control the disease.

The practice of available prevention methods for COVID-19 in the community should be assessed to design appropriate interventions that can reduce community transmission. However, there is a lack of community-based evidence that discovered how the community is preventing the pandemic of COVID-19 in Ethiopia. Therefore, this study aimed to identify factors associated with the community prevention practices of COVID-19 in three zones of southwest Ethiopia (Kafa, Bench Sheko and West Omo), where peoples are living far away from the center with inadequate infrastructures including health institutions.

\section{Materials and Methods Study Design, Setting and Period}

A community-based cross-sectional study was conducted in the Bench Sheko, Kafa, and West Omo zones from May 1 to 31,2020 . These three zones are found at $585 \mathrm{~km}, 449 \mathrm{~km}$ and $708 \mathrm{~km}$ from Addis Ababa, Capital of Ethiopia, respectively, to the southwest direction. The Bench-Sheko zone is administratively divided into six woredas (districts) and two town administrations. The Kafa zone is also divided into eleven woredas and two town administrations. Likewise, the West-Omo Zone has seven woredas. The main agro-ecology of these three zones includes dega (cool and humid high lands, which account for $56.7 \%$ of the land size), kolla (warm, semi-arid lowlands, which account for $28 \%$ of the land size) and weinadega (temperate, cool and sub-humid high lands, which account for $15.3 \%$ ). Their annual mean temperature ranges from $15.1^{\circ} \mathrm{C}$ to $27^{\circ} \mathrm{C}$, and the annual mean rainfall ranges between $400 \mathrm{~mm}$ and $2000 \mathrm{~mm}$. In these zones, there were 7 hospitals, 97 health centres and 565 health posts that provide health services for residents. According to the population projection of Ethiopia figured for 2014 to 2017, the Bench-Maji zone (the former collective name for Bench Sheko Zone and West Omo Zone before their disunion) had a total population of 847,168 (417,751 males and 429,417 females). Similarly, the Kafa Zone had a population size of $1,102,278$ (541,682 males and 560,596 females). ${ }^{18}$ 


\section{Population and Sampling Techniques}

The adult population who were 18 years old and above were included in this study. Individuals who were unable to respond due to different medical problems were excluded. The sample size was determined using a single population proportion formula $\left[n=\frac{\left(Z a_{/ 2}\right)^{2} p(1-p)}{d^{2}}\right]$, where " $n$ " stands for sample size, " $z_{\alpha / 2}$ " stands for the reliability coefficient of standard error at the $5 \%$ level of significance, which equals to 1.96, "p" stands for the proportion of good COVID-19 prevention practice, which was considered as $50 \%$ (since there was no previous study at comparable area), and "d" stands for the level of standard error tolerated, taken as $5 \%$. The calculated sample was 384.16. After using the design effect of 2 and adding a non-response rate of $10 \%$, the final sample size became 845 .

A multistage sampling technique was employed to select the study participants. First, ten woredas and town administrations (three from Bench Sheko, three from West Omo and four from Kafa) were selected randomly and included in the study. Likewise, thirty percent of Kebeles (smallest administrative units) were selected from each of the selected woredas and town administrations. Then, the calculated samples were allocated to each of the selected Kebeles proportional to the size of households in the Kebeles. Finally, the households were selected using a systematic random sampling technique, and from each of the selected households, one eligible participant was selected by the lottery method.

\section{Data Collection Technique and Data Quality Control}

A pretested interviewer-administered structured questionnaire (see Additional File 1) adapted from WHO recommendations regarding COVID-19 prevention practices and a previous similar study was used to collect the data. ${ }^{15,19,20}$ The tool includes the sociodemographic characteristics of the study participants (age, sex, religion, residence, ethnicity, marital status, occupational status, educational status, family size), knowledge questions about COVID-19 (which includes about clinical symptoms, transmission, risk factors, treatment, and vulnerable groups), attitude questions (mainly about the success of the control at an individual and national level, the effectiveness of local treatments such as hot drinks, and the probability of the occurrence of the virus in the locality), practice questions (about risky and positive behaviors practiced recently) and others. The questionnaire was prepared in English and translated to the local language
(Amharic) by a language expert. It was also back-translated to English by another expert to ensure its consistency. The Amharic version questionnaire was used to collect the data. To assure the quality of the data, two days of training was given before data collection for data collectors and supervisors about the objective of the study, techniques of data collection, different ethical issues, and care to be taken regarding COVID-19 during data collection. A pretest was performed on $10 \%$ of the total sample size in the comparable Kebeles that were not included in the actual study, and some modifications were added to the tool. We have checked the internal validity of the questionnaires used in this study using Pearson's correlation coefficient (r). The knowledge, attitude and practice questionnaires were checked separately and the calculated $r$ were significantly higher than the critical value ( $r=0.069$ with the degree of freedom $=801$ and two sided $\alpha=0.05$ ) which suggests the validity of each items. The minimum calculated $r$ for the knowledge, attitude and practice items were $0.153(\mathrm{p}<0.001), 0.285(\mathrm{p}<0.001)$ and $0.424(\mathrm{p}<0.001)$ respectively. Data were collected by thirty diploma nurses, and the overall collection process was supervised by ten BSc nurses. The supervisors checked each filled questionnaire for completeness during the data collection.

\section{Variables and Measurement}

The outcome variable of this study was the practice of COVID-19 prevention methods. The independent variables were sociodemographic characteristics (age, sex, residence, ethnicity, marital status, occupational status, educational status, family size), knowledge about COVID-19, attitude toward COVID-19 prevention methods, intention to seek care and perceived mortality.

The participants were asked 14 knowledge questions, 9 attitude questions, and 8 practice questions. Participants who scored at least the mean score of the above questions for each category were considered to have good knowledge, a positive attitude, and good practice.

\section{Data Entry, Processing and Analysis}

Data were entered into Epi data manager version 4.0.2.101 and exported to Statistical Packages for Social Science (SPSS) version 20 for analysis. Data were cleaned to check for outliers and miscoded variables. Furthermore, negatively worded items were reverse scored. Data were presented as tables and proportions (percentages). Binary logistic regression was used to assess the association between the independent variables and an outcome 
variable. The outcome variable (prevention practice) was categorized in to good practice (coded as 1) and poor practice (coded as 0 ). The odds ratio (OR) with its respective $95 \%$ confidence interval $(\mathrm{CI})$ and the p-value was used to measure the strength of the association. In the bivariable analysis, variables with $\mathrm{p}$-values $<0.25$ were considered as candidates for a multivariable analysis. The final significance was declared at a $\mathrm{p}$-value $<0.05$.

\section{Result}

\section{Characteristics of the Study Participants}

In this study, out of the 845 total samples, 803 fully participated, resulting in a response rate of $95 \%$. Among the total study participants, more than half were males (57.8\%), Orthodox Tewahido religion followers (56.4\%), and found in the age category of $18-30$ years old (52.8\%). Similarly, approximately one-third of the respondents had Kafa ethnicity (31.1\%) and single marital status (32.1\%). Furthermore, approximately two-thirds of the study participants had urban residence (67.7\%), good knowledge about COVID-19 (64.6\%), and a positive attitude toward COVID-19 (66\%). [Table 1]

\section{Practice of COVID-19 Prevention Methods Among Study Participants}

Approximately two-thirds (64.7\%) of the respondents had a history of going to crowded places. However, only approximately one-third (30.3\%) of the total study participants had a history of wearing a mask when leaving home. The majority (68.1\%) of the study participants had a history of covering their mouth and nose when coughing and sneezing. Twothirds of the respondents had a history of maintaining their distance at 2 meters (64.4\%) and washing their hands with soap and water or using alcohol-based hand sanitizers (64.8\%). However, a significant proportion (45.6\%) of them had a history of eating raw/uncooked foods. Generally, less than two-thirds (59.4\%) of study subjects had a good practice of COVID-19 prevention methods. [Table 2]

\section{Factors Associated with Prevention Practices of COVID-19}

In bivariable logistic regression, residence, educational status, occupation, marital status, family size, knowledge, attitude, intention to seek care and perceived mortality were statistically significant at p-values less than 0.25 . After controlling for confounders, in multivariable logistic regression, residence, knowledge status, attitude status, intention to seek care, and perceived mortality were significantly associated with the COVID-19 prevention practices of the participants at a p-value less than 0.05 .

Urban residents had more than two ( $\mathrm{AOR}=2.34)$ times higher odds of good practice compared to rural residents. Similarly, participants who were from the highest family size (more than six) had three $(\mathrm{AOR}=2.95)$ times higher odds of good practice than those from the lowest (one to three) family size. Good knowledge status $(\mathrm{AOR}=1.74)$ and positive attitude $(\mathrm{AOR}=1.86)$ had a positive influence on COVID-19 prevention practices compared to their counterparts (poor knowledge and negative attitude, respectively). Furthermore, respondents who had the intention to seek care for COVID-19 symptoms had $73 \%$ $(\mathrm{AOR}=1.73)$ increased odds of good practice than those who had no intention. Lastly, individuals who had a perception of COVID-19-related death had double $(A O R=2.20)$ odds of good practice than those who had no such perception. [Table 3]

\section{Discussion}

This study revealed that approximately two-thirds (64.7\%) of the respondents had a history of going to a crowded place, which is comparable to the finding of the study conducted at Jimma University Medical Center (JUMC). ${ }^{21}$ However, it is very high compared to the study conducted in China, ${ }^{19}$ where only $3.6 \%$ visited crowded places. The discrepancy might be due to the differences in socio-economic and demographic characteristics between the two countries. Compared to Chinese, Ethiopians' lower economic status may increase their probability of going to crowded places since there is difficulty in accessing technologies to communicate virtually and to use online businesses. Moreover, the strong social interactions in Ethiopian society may oblige people to go to crowded areas. ${ }^{22}$ Since COVID-19 has a higher potential of person-to-person transmission, exposure to crowded places is risky behavior and should be discouraged.

One of the important findings in this study is that only one-third (30.3\%) of the study participants had a history of wearing a protective mask when leaving home. This is very low compared to the finding from China, ${ }^{19}$ and it is also contrary to the WHO recommendations. ${ }^{21}$ This figure is very frustrating in the case of Ethiopia, where the community transmission of COVID-19 is more likely. ${ }^{9,11}$ An additional finding that magnifies the problem of COVID19 prevention practice is that a significant proportion 
Table I The Characteristics of the Study Participants in the Bench Sheko, Kafa, and West Omo Zones, South West Ethiopia, 2020

\begin{tabular}{|c|c|c|c|}
\hline Variables & Category & $\begin{array}{l}\text { Frequency } \\
(803)\end{array}$ & $\begin{array}{l}\text { Percentage } \\
\text { (\%) }\end{array}$ \\
\hline \multirow[t]{2}{*}{ Sex } & Male & 464 & 57.8 \\
\hline & Female & 339 & 42.2 \\
\hline \multirow[t]{2}{*}{ Residence } & Urban & 544 & 67.7 \\
\hline & Rural & 259 & 32.3 \\
\hline \multirow[t]{3}{*}{ Age } & $18-30$ & 423 & 52.8 \\
\hline & $31-40$ & 223 & 27.8 \\
\hline & $>40$ & 156 & 19.4 \\
\hline \multirow[t]{6}{*}{ Ethnicity } & Bench & 133 & 16.6 \\
\hline & Sheko & 102 & 12.7 \\
\hline & Amhara & 112 & 13.9 \\
\hline & Kafa & 150 & 31.1 \\
\hline & Oromo & 94 & 11.7 \\
\hline & Others ${ }^{\mathrm{a}}$ & 112 & 13.9 \\
\hline \multirow[t]{5}{*}{ Marital status } & Single & 258 & 32.1 \\
\hline & Married & 435 & 54.2 \\
\hline & Divorced/ & 74 & 9.2 \\
\hline & widowed & & \\
\hline & Separated & 36 & 4.5 \\
\hline \multirow{8}{*}{$\begin{array}{l}\text { Occupational } \\
\text { status }\end{array}$} & Unemployed & 93 & 11.6 \\
\hline & Farmer & 161 & 20 \\
\hline & Daily laborer & 96 & 12 \\
\hline & Merchant & 135 & 16.8 \\
\hline & Government & $14 \mid$ & 17.6 \\
\hline & $\begin{array}{l}\text { employee } \\
\text { Private }\end{array}$ & 113 & 14.1 \\
\hline & business & & \\
\hline & Students & 64 & 8 \\
\hline \multirow[t]{5}{*}{ Educational status } & $\begin{array}{l}\text { Cannot read } \\
\text { and write }\end{array}$ & 155 & \\
\hline & $\begin{array}{l}\text { Can read and } \\
\text { write }\end{array}$ & 149 & 18.6 \\
\hline & $\begin{array}{l}\text { Primary } \\
\text { (grade I-8) }\end{array}$ & 176 & 21.9 \\
\hline & $\begin{array}{l}\text { Secondary or } \\
\text { preparatory }\end{array}$ & 142 & 17.7 \\
\hline & $\begin{array}{l}\text { Diploma and } \\
\text { above }\end{array}$ & 181 & 22.5 \\
\hline \multirow[t]{4}{*}{ Religion } & $\begin{array}{l}\text { Orthodox } \\
\text { Tewahido }\end{array}$ & 453 & 56.4 \\
\hline & Muslim & 99 & 12.3 \\
\hline & Protestant & 207 & 25.8 \\
\hline & Other ${ }^{b}$ & 44 & 5.5 \\
\hline \multirow[t]{2}{*}{ Family size } & One to three & 390 & 48.6 \\
\hline & Four to six & 341 & 42.5 \\
\hline
\end{tabular}

Table I (Continued).

\begin{tabular}{|l|l|l|l|}
\hline Variables & Category & $\begin{array}{l}\text { Frequency } \\
\text { (803) }\end{array}$ & $\begin{array}{l}\text { Percentage } \\
\text { (\%) }\end{array}$ \\
\hline & $\begin{array}{l}\text { Seven and } \\
\text { more }\end{array}$ & 72 & 9 \\
\hline $\begin{array}{l}\text { Perceived } \\
\text { mortality of } \\
\text { COVID-19 }\end{array}$ & Yes & 347 & 43.2 \\
\hline Knowledge & $\begin{array}{l}\text { Good } \\
\text { Poor }\end{array}$ & 519 & 64.6 \\
Attitude & $\begin{array}{l}\text { Positive } \\
\text { Negative }\end{array}$ & $\begin{array}{l}530 \\
273\end{array}$ & $\begin{array}{l}66 \\
34\end{array}$ \\
\hline $\begin{array}{l}\text { Intend to seek } \\
\text { care }\end{array}$ & $\begin{array}{l}\text { Have } \\
\text { intention } \\
\text { Have no } \\
\text { intention }\end{array}$ & 345 & 57 \\
\hline
\end{tabular}

Notes: ${ }^{\mathrm{M}}$ Menit and Dizu; ${ }^{\mathrm{b}} \mathrm{C}$ atholic and traditional belief.

(35.6\%) of people did not maintain appropriate physical distance. As a result, efforts should be made to encourage the public to use a protective mask and maintain appropriate physical distance as per the WHO recommendations.

Our findings show that only three of five participants had good COVID-19 prevention practices. This is very low compared to the Iranian finding, ${ }^{23}$ and the discrepancy might be attributable to the differences in socio-economic statuses and attention given by the community. The better socio-economic status of Iranians may enable them to access different inputs required to prevent COVID-19. The increased number of cases and deaths in Iran could also bring more attention to prevent COVID-19 among Iranians compared to Ethiopians. ${ }^{24,25}$

This finding is highly public health important for Ethiopia, which was grouped as among vulnerable African countries to COVID-19. ${ }^{26}$ This is because the provision of important health services to COVID-19 patients requires expensive resources, and in Ethiopia, the majority of the health services are substandard mainly due to resource scarcity. ${ }^{16,17}$ For instance, Ethiopia had 557 mechanical ventilators and 570 intensive care unit (ICU) beds for a population of 110 million. ${ }^{9}$ Thus, a major emphasis on prevention is mandatory, and sustainable intervention should be made to increase its implementation. 
Table 2 Practice of COVID-I9 Prevention Methods Among Study Participants in Bench Sheko, Kafa and West Omo Zones, South West Ethiopia, 2020

\begin{tabular}{|c|c|c|}
\hline Question/Variables/ & Response/Categories/ & $\mathbf{N}(\%)$ \\
\hline \multirow[t]{2}{*}{ Recent history of going to any crowded place } & Yes & $518(64.7)$ \\
\hline & No & $283(35.3)$ \\
\hline \multirow[t]{2}{*}{ Recent history of wearing a mask when leaving home } & Yes & $243(30.3)$ \\
\hline & No & $558(69.7)$ \\
\hline \multirow[t]{2}{*}{ Recent history of washing hands with soap and water frequently or using alcohol-based hand sanitizers } & Yes & $520(64.8)$ \\
\hline & No & $283(35.2)$ \\
\hline \multirow[t]{2}{*}{ A recent habit of touching eye, nose, and mouth } & Yes & $503(62.6)$ \\
\hline & No & $300(37.4)$ \\
\hline \multirow[t]{2}{*}{ Recent history of covering mouth and nose when coughing and sneezing } & Yes & $547(68.1)$ \\
\hline & No & $256(31.9)$ \\
\hline \multirow[t]{2}{*}{ Recent history of maintaining physical distance at 2 meters } & Yes & $515(64.4)$ \\
\hline & No & $285(35.6)$ \\
\hline \multirow[t]{2}{*}{ Recent history of eating raw/uncooked foods } & Yes & $366(45.6)$ \\
\hline & No & $437(54.4)$ \\
\hline \multirow[t]{2}{*}{ Recent history of shaking hands of others } & Yes & $308(38.4)$ \\
\hline & No & $495(61.6)$ \\
\hline \multirow[t]{2}{*}{ Overall practice } & Good & $477(59.4)$ \\
\hline & Poor & $326(40.6)$ \\
\hline
\end{tabular}

In this study, participants from urban residents had more than two times higher odds of practice than those from rural residents. This might be because urban residents had better access to COVID-19-related information and resources needed to prevent COVID-19, such as alcohol-based sanitizers, soap, water, and protective masks. In addition, the rural community may not obtain adequate information regarding COVID-19 due to limited access to phone and/or internet, which is common for the rural community of Ethiopia. ${ }^{9}$

One of the opportunities during the era of COVID-19 is an increased time for discussion and interaction among family members. ${ }^{27}$ This opportunity enables the parents to implement different innovations to protect themselves and their family members from the pandemic of COVID-19 and its impacts such as mental health problems. ${ }^{28}$ In our study higher family size (more than six) had three times higher odds of practice compared to those with lower family size. Members of an increased family size probably bring information related to COVID-19 prevention from different sources and discuss it, which could enable them to change it into practice.

Participants with good knowledge status about COVID-19 had more than one and a half times higher odds of practice compared to those with poor knowledge status. This is also supported by the previous finding where knowledge and practice were associated with direct proportionality. ${ }^{19}$ Most of the time, it is straightforward that having knowledge enables people to practice what they know. People who have good knowledge about the disease, its severity, transmission methods, and prevention methods can value their lives and take appropriate measures.

Likewise, individuals with a positive attitude regarding the success of COVID-19 prevention methods had $86 \%$ increased odds of good practice compared to those with a negative attitude. It is obvious that when people rely on the success of prevention methods, their interest in applying these methods will be high. Therefore, the information should be disseminated continuously to increase the trust of the community in prevention methods and to avoid their concentration on fake news that discourages preventive behaviors.

In our study, respondents who perceived that COVID19 can lead to death, had two times higher odds of good practice of preventive measures against COVID-19 compared to their counterparts. People in the world prefer to 
Table 3 Factors Associated with Prevention Practices of COVID-19 Among the Study Participants in Bench Sheko, Kafa and West Omo Zones, South West Ethiopia, 2020

\begin{tabular}{|c|c|c|c|c|c|c|}
\hline \multirow[t]{2}{*}{ Variables } & \multirow[t]{2}{*}{ Category } & \multicolumn{2}{|c|}{ Practice } & \multirow[t]{2}{*}{ COR $(95 \% \mathrm{CI})$} & \multirow[t]{2}{*}{ AOR $(95 \% \mathrm{Cl})$} & \multirow[t]{2}{*}{ P-value } \\
\hline & & No & Yes & & & \\
\hline Residence & $\begin{array}{l}\text { Urban } \\
\text { Rural }\end{array}$ & $\begin{array}{l}146 \\
180\end{array}$ & $\begin{array}{l}398 \\
79\end{array}$ & $\begin{array}{l}6.21(4.49,8.60) \\
1\end{array}$ & $\begin{array}{l}2.34(1.39,3.94) \\
1\end{array}$ & $0.001 *$ \\
\hline Educational status & $\begin{array}{l}\text { Cannot read and write } \\
\text { Can read and write } \\
\text { Primary } \\
\text { Secondary } \\
\text { Diploma and above }\end{array}$ & $\begin{array}{l}101 \\
60 \\
71 \\
56 \\
38\end{array}$ & $\begin{array}{l}54 \\
89 \\
105 \\
86 \\
143\end{array}$ & $\begin{array}{l}\text { I } \\
2.77(1.74,4.42) \\
2.77(1.77,4.33) \\
2.87(1.79,4.60) \\
7.04(4.33,11.45)\end{array}$ & $\begin{array}{l}\text { I } \\
\text { I.04 }(0.58,1.87) \\
\text { I.I2 }(0.62,2.01) \\
1.08(0.58,2.01) \\
1.65(0.82,3.33)\end{array}$ & $\begin{array}{l}0.904 \\
0.707 \\
0.813 \\
0.160\end{array}$ \\
\hline Occupation & $\begin{array}{l}\text { Unemployed } \\
\text { Farmer } \\
\text { Daily labor } \\
\text { Merchant } \\
\text { Government employee } \\
\text { Private business } \\
\text { Students }\end{array}$ & $\begin{array}{l}42 \\
121 \\
30 \\
38 \\
31 \\
44 \\
20\end{array}$ & $\begin{array}{l}51 \\
40 \\
66 \\
97 \\
110 \\
69 \\
44\end{array}$ & $\begin{array}{l}1 \\
0.27(0.16,0.47) \\
1.81(1.00,3.28) \\
2.10(1.21,3.66) \\
2.92(1.65,5.17) \\
1.29(0.74,2.25) \\
1.81(0.93,3.53)\end{array}$ & $\begin{array}{l}\text { I } \\
0.68(0.35,1.33) \\
1.72(0.84,3.5 \mathrm{I}) \\
\mathrm{I} .54(0.8 \mathrm{I}, 2.93) \\
\mathrm{I} .64(0.78,3.48) \\
0.99(0.5 \mathrm{I}, \mathrm{I} .93) \\
\mathrm{I} .50(0.69,3.24)\end{array}$ & $\begin{array}{l}0.264 \\
0.136 \\
0.191 \\
0.194 \\
0.976 \\
0.303\end{array}$ \\
\hline Marital status & $\begin{array}{l}\text { Single } \\
\text { Married } \\
\text { Divorced/Widowed } \\
\text { Separated }\end{array}$ & $\begin{array}{l}94 \\
190 \\
30 \\
12\end{array}$ & $\begin{array}{l}164 \\
245 \\
44 \\
24\end{array}$ & $\begin{array}{l}\text { I } \\
0.74(0.54,1.01) \\
0.84(0.50,1.43) \\
I .15(0.55,2.40)\end{array}$ & $\begin{array}{l}I \\
0.70(0.46,1.05) \\
0.93(0.49,1.77) \\
0.94(0.40,2.17)\end{array}$ & $\begin{array}{l}0.081 \\
0.832 \\
0.877\end{array}$ \\
\hline Family size & $\begin{array}{l}\text { One to three } \\
\text { Four to six } \\
\text { More than six }\end{array}$ & $\begin{array}{l}166 \\
137 \\
23\end{array}$ & $\begin{array}{l}224 \\
204 \\
49\end{array}$ & $\begin{array}{l}\text { I } \\
\text { I.IO }(0.82,1.48) \\
\text { I.58 }(0.93,2.69)\end{array}$ & $\begin{array}{l}\text { I } \\
1.37(0.94,1.99) \\
2.95(1.56,5.57)\end{array}$ & $\begin{array}{l}0.098 \\
0.001 *\end{array}$ \\
\hline Knowledge status & $\begin{array}{l}\text { Poor } \\
\text { Good }\end{array}$ & $\begin{array}{l}189 \\
137\end{array}$ & $\begin{array}{l}95 \\
382\end{array}$ & $\begin{array}{l}\text { I } \\
5.55(4.05,7.60)\end{array}$ & $\begin{array}{l}\text { I } \\
\text { I.74 (I.10, 2.77) }\end{array}$ & $0.019 *$ \\
\hline Attitude status & $\begin{array}{l}\text { Negative } \\
\text { Positive }\end{array}$ & $\begin{array}{l}167 \\
159\end{array}$ & $\begin{array}{l}106 \\
371\end{array}$ & $\begin{array}{l}\text { I } \\
3.68(2.71,4.99)\end{array}$ & $\begin{array}{l}\text { I } \\
\text { I.86 (I.27, 2.73) }\end{array}$ & $0.001 *$ \\
\hline Intend to seek care & $\begin{array}{l}\text { No intention } \\
\text { Have intention }\end{array}$ & $\begin{array}{l}210 \\
116\end{array}$ & $\begin{array}{l}135 \\
342\end{array}$ & $\begin{array}{l}\text { I } \\
4.59(3.39,6.20)\end{array}$ & $\begin{array}{l}\text { I } \\
\text { I.73 (I.13, 2.63) }\end{array}$ & $0.011 *$ \\
\hline Perceived mortality & $\begin{array}{l}\text { Yes } \\
\text { No }\end{array}$ & $\begin{array}{l}171 \\
155\end{array}$ & $\begin{array}{l}176 \\
301\end{array}$ & $\begin{array}{l}\text { I } \\
\text { I.89 (I.42, 2.5I) }\end{array}$ & $\begin{array}{l}\text { I } \\
2.20(1.50,3.08)\end{array}$ & $0.000 *$ \\
\hline
\end{tabular}

Note: *Statistically significant at $\mathrm{p}$-value $<0.05$.

Abbreviations: AOR, adjusted odds ratio; $\mathrm{Cl}$, confidence interval; $\mathrm{COR}$, crude odds ratio.

live long on the earth and invest to alleviate the risk of death as much as possible. Educating the community about the severe outcome of the COVID-19 could benefit them to have appropriate prevention behaviors. However, this should be done in a manner that will not bring an exaggerated panic to the community.

\section{Limitations}

This is the self-reported practice of COVID-19 prevention methods, and there may be the probability of social desirability bias. Since we have used a cross-sectional study design it may be difficult to establish the temporal relationship between the outcome variable and some of the independent variables. Lastly, the findings can be generalizable to the comparable settings in Ethiopia; but to the other parts, this should be done with cautions.

\section{Conclusion}

The proportion of individuals who had good COVID-19 prevention practices was inadequate in our study area. Moreover, the practice of wearing a protective mask and maintaining recommended physical distance is very low, 
and these all need immediate interventions. It was also demonstrated that urban residents had good practice compared to rural residents. This gap should be addressed by educating rural dwellers and availing important inputs for COVID-19 prevention methods, keeping in mind that $79 \%$ of Ethiopians are living in rural areas with weak transportation and communication links. ${ }^{9}$ The respondents had moderate knowledge and attitudes about COVID-19, which had a positive influence on good practice. Thus, it is also important to center the interventions on updating the knowledge and attitude of respondents. This can also enhance the community's perceived mortality, which was recognized as a significant predictor of good practice. Overall, for such highly infectious disease prevention should be a priority intervention, and the prevention practice of the community in our study area needs further effort.

\section{Abbreviations}

AOR, adjusted odds ratio; CI, Confidence Interval; COVID-19, Coronavirus Disease 2019; EPHI, Ethiopian Public Health Institute; ICU, Intensive Care Unit; JUMC, Jimma University Medical Center; OR, Odds Ratio, SPSS, Statistical Package for Social Sciences; WHO, World Health Organization.

\section{Data Sharing Statement}

The datasets used during the current study are available with authors and can be obtained from the corresponding author on reasonable request.

\section{Ethical Considerations}

This study was conducted in accordance with the Declaration of Helsinki. The study protocol was approved by the ethical review committee of the health science college of Mizan Tepi University, and the approval letter with a reference number $\mathrm{HSC} / 0032 / 20$ was obtained. In addition, the support letter was obtained from Mizan Tepi University and given to the zonal administrations of Kafa, Bench-Sheko and West Omo zones. Then permission letter was obtained from local authorities (each zonal administrations) to conduct the study in the selected Kebeles of each zones. The study participants were briefed about the purpose of the study, their right to participate or not, and the quitting of participation at any point of time during the data collection. Written informed consent was obtained from each participant. The possible prevention methods of COVID-19 (wearing a protective facemask and keeping at least 2 meters of physical distance) were implemented during data collection. The data were collected anonymously and kept confidential.

\section{Acknowledgments}

The authors are grateful for Mizan-Tepi University which funded this study. The authors would also like to acknowledge the supervisors, data collectors, and study participants for their participation in this research and the local government bodies for their unreserved support.

\section{Funding}

The fund for this study was obtained from Mizan Tepi University.

\section{Disclosure}

The authors have declared no conflicts of interest for this work.

\section{References}

1. Lu H, Stratton CW, Tang YW. Outbreak of pneumonia of unknown etiology in Wuhan, China: the mystery and the miracle. J Med Virol. 2020;92:401-402. doi:10.1002/jmv.25678

2. Austin Price. The lasting impact of the COVID-19 pandemic on our healthcare delivery system | Berkeley News. Berkeley, University of Calfornia; 2020 [cited May 14, 2020]. Available from: https://news. berkeley.edu/2020/05/04/the-lasting-impart-of-the-covid-19pandemic-on-our-healthcare-delivery-system/. Accessed December 10, 2020.

3. Lai C, Wang C, Wang Y, Hsueh S, Ko W, Hssueh P-R. Global epidemiology of coronavirus disease 2019 (COVID-19): disease incidence, daily cumulative index, mortality, and their association with country healthcare resources and economic status. Int $J$ Antimicrob Agents. 2020;55(4):105946. doi:10.1016/j. ijantimicag.2020.105946

4. International Labor Organization. COVID-19 and the world of work: impact and policy responses; March 2020:1-15. Available from: http://hdl.voced.edu.au/10707/533608. Accessed December 10, 2020.

5. Maor M, Suliteazonu-Kenan R, Chinitz D. When COVID-19, constitutional crisis, and political deadlock meet: the Israeli case from a disproportionate policy perspective. J Policy Soc. 2020;39(3).

6. Oldekop JA, Horner R, Hulme D, et al. COVID-19 and the case for global development. World Dev. 2020;134:1-4. doi:10.1016/j. worlddev.2020.105044

7. World Health Organization (WHO). Coronavirus disease (COVID-19) pandemic- Situational Update. WHO; 2020 [cited December 3, 2020]. Available from: https://covid19.who.int/. Accessed December 10, 2020.

8. World Health Organization (WHO). First Case of COVID-19 Confirmed in Ethiopia. WHO; 2020 [cited August 1, 2020]. Available from: https://www.afro.who.int/news/first-case-covid-19confirmed-ethiopia. Accessed December 10, 2020.

9. Shigute Z, Mebratie AD, Alemu G, Bedi A. Containing the spread of COVID-19 in Ethiopia. J Glob Health. 2020;10(1):1-4. doi:10.7189/ jogh.10.010369

10. Ethiopian Public Health Institute (EPHI). Status update on COVID19 Ethiopia. EPHI; 2020 [cited December 3, 2020]. Available from: https://covid19.ephi.gov.et/status-update-on-covid19-ethiopiadecember-2-2020/. Accessed December 10, 2020. 
11. Biadgilign S, Yigzaw M. COVID-19 in Ethiopia: current situation, missed opportunities, and the risk of health system disruptions. Pan Afr Med J. 2020;35(2):66. doi:10.11604/pamj.supp.2020.35.2.23906

12. World Health Organization (WHO). Attacks on health care in the context of COVID-19. WHO; 2020 [cited December 4, 2020]. Available from: https://www.who.int/news-room/feature-stories /detail/attacks-on-health-care-in-the-context-of-covid-19. Accessed December 10, 2020.

13. Apolitical. How Ethiopia's community health workers are hunting down Covid-19; 2020 [cited December 4, 2020]. Available from: https:// apolitical.co/en/solution article/how-ethiopias-community-healthworkers-are-hunting-down-covid-19. Accessed December 10, 2020.

14. World Health Organization (WHO), IFRC and, unicef. Communitybased health care, including outreach and campaigns, in the context of the COVID-19 pandemic: interim guidance. WHO; 2020:1-43. Available from: https:/www.who.int/publications/i/item/communitybased-health-care-including-outreach-and-campaigns-in-the-contextof-the-covid-19-pandemic. Accessed December 10, 2020.

15. World Health Organization (WHO). Coronavirus disease (COVID-19) advice for the public. WHO; 2020 [cited August 3, 2020]. Available from: https://www.who.int/emergencies/diseases/novel-coronavirus -2019/advice-for-public. Accessed December 10, 2020.

16. Haileamlak A. How can Ethiopia mitigate the health workforce gap to meet universal health coverage? Ethiop J Health Sci. 2018;28 (3):249-250. doi:10.4314/ejhs.v28i3.1

17. World Health Organization (WHO). Health workforce requirements for universal health coverage and the sustainable development goals. Human Resource for Health Observers Series No. 17. WHO; 2016 [cited May 23, 2020]. Available from: https://www.who.int/hrh/ resources/health-observer17/en/.

18. Federal Democratic Republic of Ethiopia Central Statistical Agency. Population projection of Ethiopia for all regions at Wereda level from 2014 - 2017; 2013:1-118. Available from: https://www.scribd.com/ document/343869975/Population-Projection-At-Wereda-Level-from2014-2017-pdf.

19. Zhong B, Luo W, Li H, et al. Knowledge, attitudes, and practices towards COVID-19 among Chinese residents during the rapid rise period of the COVID-19 outbreak: a quick online cross-sectional survey. Int $J$ Biol Sci. 2020;16(10):1745-1752. doi:10.7150/ ijbs. 45221
20. World Health Organization (WHO). Risk communication and community engagement (RCCE) action plan guidance COVID-19 preparedness and response; 2020. Available from: https://www.who.int/ publications/i/item/risk-communication-and-community-engagement(rcee)-action-plan-guidance.

21. Kebede Y, Yitayih Y, Birhanu Z, Mekonen S, Ambelu A. Knowledge, perceptions and preventive practices towards COVID-19 early in the outbreak among Jimma university medical center visitors, Southwest Ethiopia. PLoS One. 2020;1-15.

22. Duguma LA, Hager H. Farmers' assessment of the social and ecological values of land uses in central highland Ethiopia. Environ Manage. 2011;47:969-982. doi:10.1007/s00267-011-9657-9

23. Erfani A, Shahriarirad R, Ranjbar K, Mirahmadizadeh A, Moghadami M. Knowledge, attitude and practice toward the novel coronavirus (COVID-19) outbreak: a population-based survey in Iran. Bull World Health Organ. 2020;1-22. doi:10.2471/ BLT.20.251561

24. World Health Organization (WHO). Coronavirus disease 2019 (COVD-19) situatonal update of Islamic Republic of Iran. WHO; 2020 [cited December 3, 2020]. Available from: https://covid19. who.int/region/emro/country/ir. Accessed December 10, 2020.

25. Mehdi SZ Confusion raises Iranian fears from coronavirus. Anadolu Agency; 2020 [cited December 3, 2020]. Available from: https:// www.aa.com.tr/en/health/confusion-raises-iranian-fears-fromcoronavirus/1745093\#. Accessed December 10, 2020.

26. Gilbert M, Pullano G, Pinotti F, et al. Preparedness and vulnerability of African countries against importations of COVID-19: a modelling study. Lancet. 2020;395:871-877. doi:10.1016/S0140-6736(20) 30411-6

27. Wondimu W, Girma B. Challenges and silver linings of COVID-19 in Ethiopia - short review. J Multidiscip Healthc. 2020;13:917-922. doi:10.2147/JMDH.S269359

28. Szabo TG, Richling S, Embry DD, Biglan A, Wilson KG. From helpless to hero: promoting values-based behavior and positive family interaction in the midst of COVID-19. Behav Anal Pract. 2020;13:568-576. doi:10.1007/s40617-020-00431-0
International Journal of General Medicine

\section{Publish your work in this journal}

The International Journal of General Medicine is an international, peer-reviewed open-access journal that focuses on general and internal medicine, pathogenesis, epidemiology, diagnosis, monitoring and treatment protocols. The journal is characterized by the rapid reporting of reviews, original research and clinical studies across all disease areas. The manuscript management system is completely online and includes a very quick and fair peer-review system, which is all easy to use. Visit http://www.dovepress.com/ testimonials.php to read real quotes from published authors. 